\title{
Gilles Deleuze Felsefesinde Temel Kavramlar ve Yeni Toplumsal Hareketler
}

\author{
DOI: 10.26466/opus.589030
}

\begin{abstract}
$*$
\section{Ümmet Erkan*}

* Dr. Öğr.Üyesi, Bartın Üniversitesi Edebiyat Fakültesi Sosyoloji Böl., Merkez/Bartın / Türkiye E-Posta: uerkan@bartin.edu.tr ORCID:0000-0002-7806-4886
\end{abstract}

\section{Öz}

Deleuze yapısalcillk sonrası Fransız felsefesinin en üretken isimlerinden biridir. Onun eserleri sinemadan sosyolojiye, psikiyatriden edebiyata kadar çeşitli alanlarda farklı okumalara olanak sağlamıştır. Onun düşünce çerçevesini belirleyen filozoflar Nietzsche, Spinoza, Hume, Bergson ve Marks'tır. Yaşamı olumlayan, arzuyu merkeze alan Deleuze felsefesi yaratıcı bir çokluk içerir. Deleuze felsefesi 1968 sonrası felsefede etkili olan postmodern felsefelere dayanır. Hakikatin çoğullaşması ve meta anlatıları ölümü ile birlikte klasik toplumsal hareketler de zayıflamıştır. Dijitalleşen toplum, enformasyona dayalı yeni üretim ve tüketim ağı, mobil hale gelen sermaye buna zemin hazırlamıştır. Küresel bir nitelik kazanan ve yersizyurdsuzlaşan sermaye ağına karşı çokluğu merkeze alan yeni bir toplumsal hareketlere gereksinim duyulmuştur. Deleuze düşüncesi birbirine eklemlenip bir köksap oluşturabilen ve kendi tekilliklerini kaybetmeyen bir çokluk amaçlar. Bu çokluk tekliğe indirgenemez. Bu çokluk aynı zamanda kod bozucu olduğu için sistem, sermaye tarafindan da ele geçirilemez. Bu çalışmada Deleuze'ün felsefi düşüncesi, ürettiğgi temel kavramlarm analiz edilmesi hedeflenmiştir. Onun felsefi düşüncesi ve kavramlarından yola çıkarak yaratıcı çokluk ve köksaplara dayalı tekilliklerin toplumsal hareketlere etkilerinin incelenmesi amaçlanmıştır.

Anahtar Kelimeler: Deleuze, köksap, yersizyurdsuzlaşma, şizoanaliz, organsız beden. 


\title{
Basic Concepts And New Social Movements in Gilles Deleuze Philosophy
}

\begin{abstract}
G. Deleuze is one of the most productive names of French philosophy after structuralism. His works have enabled him to read in various fields from cinema to sociology, from psychiatry to literature. The philosophers who define his thinking frame are Nietzsche, Spinoza, Hume, Bergson and Marx. The philosophy of Deleuze, which affirms life and takes the center of desire, involves a creative multitude. The Deleuze philosophy is based on postmodern philosophies which were influential in philosophy after 1968. With the multiplication of truth and the death of meta-narratives, classical social movements have also weakened. The digitalized society, the new production and consumption network based on information, the capital that has become mobile has laid the ground for this. There is a need for a new social movement that is centered on a multiplicity of capital networks, which have gained a global character and are deterritorialization. Deleuze thought is a multiplicity of purposes that can be articulated together to form a rhizome and do not lose their singularity. This multitude cannot be reduced to uniqueness. The system cannot be seized by capital because this multitude is also a decoder. In this study, it is aimed to analyze Deleuze's philosophical thought and the basic concepts it produces. The aim of this course is to examine the effects of social multiplicities of singularities based on creative multiplicity and rhizome based on his philosophical thought and concepts.
\end{abstract}

Keywords: Deleuze, rhizome, deterritorialization, schizoanalysis, body without organ 


\section{Giriş}

Yapısalcilık sonrası Fransız felsefesinin en üretken isimlerinden biri olan G. Deleuze, ürettiği felsefi kavramlar ve onlara yüklediği yeni anlamlarla siyasetten sosyoloji, psikiyatriden sinemaya kadar geniş bir alanda eserler üretmiştir. Deleuze felsefesi transnasyonel sermayesinin nomadik (göçebe) bir okumasıdır. Sermaye küreselleşmiş ve geniş bir ağ içerisinde yersizyurdsuzlaşmıştır. Onun felsefi düşüncesi statik bir ontoloji ve homojenleştirici ulus devlet retoriğine değil kaygan ve pürtüksüz yüzeylerde sürekli hareket halinde olan bir oluş felsefesine dayanır. Sermayenin küreselleşmesi ve buna eşlik eden enformasyon ağları dinamik bir toplum yapısı ortaya çıkarmıştır. Esnek ve belirli bir komuta ağı olmadan işleyen enformasyon, dinamik bilgi ağları oluşmasını sağlamış toplumsal yapıda bütünlük ve homojenliğe karşı tekillik ve farkı vurgulayan felsefi söylemler güçlenmiştir. Deleuze felsefesi tekillik ve fark üzerine kurulu bir felsefedir. Farklı tekilliklerin bir köksap (rhizome) oluşturarak birbiriyle etkileşime geçmesi düşüncesine dayanır.

Deleuze felsefesi bir sistem felsefesi değildir. Onun eserlerine girmek için tek bir kapı yoktur. Hatta ortada bir kapının olup olmadığı bile tartışmalıdır. Kafka'yı incelerken söyledikleri onun eserleri için de geçerlidir. "Kafka'nın yapıtına nasıl girmeli? O bir köksap, bir yuva. Şato'nun, kullanım ve dağılım yasaları pek iyi bilinmeyen "çoğul girişleri" var... Dolayısıyla hangi uçtan girilirse girilsin hiçbiri diğerinden daha işe yarar değildir; bu neredeyse bir çıkmaz, dar, uzun bir yol, dolambaçlı bir boru vb. bile olsa, hiçbir girişin ayrıcalığı yoktur." (Deleuze ve Guittari, 2000, s.7). Onun yapıtları her biri birbirinden ayrı fakat birbirleriyle ilişki içinde olan çoğulluklardır. Tıpkı "Bin Yayla" (A Thousand Plateaus) kitabındaki her bir bölümün diğerinden ayrı bir yayla olduğu gibi. Onun yapıtları yaratıcı bir çokluk içerir. F. Guittari ile yazdıkları "Kapitalizm ve Şizofreni I-II" (Anti-Oidipus ve Bin Yayla) kitaplarında hangisinin (Deleuze ve Guittari) hangi bölümü hatta hangi cümleyi yazdığından emin olunamaz. İkisi bir köksap olarak birbirleriyle ayrı fakat yaratıcı bir etkileşim içindedirler. Tek bir ağaç fakat bu ağacın farklı dalları gibi. Bu yazım biçimi onun felsefi düşüncesiyle ilgilidir. Ona göre kitap bir çokluk, bir organsız bedendir. "Bir kitap bir düzenleme biçimidir ve asla bir özneye mal edilemez. Kitap bir çokluktur. Bir kitabın organize bir bütün 
olmadığ 1 düşüncesinden hareketle, anlamsız partikülleri, saf yoğunlukları da içinde taşıdığını göz önünde bulundurursak, bir kitabın organsız bir beden olduğu söylenir." (Deleuze, 1993, s.9)

Deleuze'e göre felsefe yaratma etkinliğidir. Ona göre felsefenin amacı hayatın yaratıcı çokluğunu, devinimini açıklayabilecek yeni kavramlar üretmektir. "Felsefe kavramlar oluşturmak, keşfetmek, üretmek sanatıdır... filozof, Kavram'ı keşfeder, onu düşünür... Filozof kavram dostudur, kavram üretme gücünü içinde taşır." (Deleuze ve Guittari, 2001, s.12-14). Bu kavramlar, onu yaratan kişilerin imzasını taşırlar. Yaratıcıları o kavramlara kendi tekillliklerini kazır. Tıpkı Descartes'in "Cogito", Kant' in "transendantal", Nietzsche'nin "güç istenci," Bergson' un "süre"si gibi. Bir filozof başkalarının kavramlarını kullandığı ölçüde o düşünceye bağımlı kalır. Bu nedenle her filozof kendi kavramlarını üretmelidir. Deleuze'e göre kavramlar tarihsel boyutta değişir, gelişir, yeni anlamlar kazanır. Kavramlar verilmiş değil, yaratılmıştır. Kavramlar "orada" ve biz tarafından keşfedilmeyi beklemezler. Onları biz bulmalı, üretmeliyiz. “Kavramlar için ayrı bir gökyüzü yoktur. Onlar keşfedilmeli, üretilmeli, ya da asıl, yaratılmalıdırlar ve yaratıcılarının imzasını taşımadıkça da bir şey olamazlar." (Deleuze ve Guittari, 2001, s.14).

Deleuze'ün düşünsel çerçevesini belirleyen kavramlar arasında; "köksap", "yersizyurdsuzlaşma", "organsız beden", "kapma aygitı", "kaçış çizgileri", "nomadik düşünce", "savaş makinası", "şizoanaliz", "arzu makinaları" önemli yer tutar. Deleuze ürettiği bu kavramlara kendi anlamlarını yüklemiştir. $\mathrm{O}$, doğa bilimlerinden matematiğe, sinemadan politikaya, sosyolojiden coğrafyaya kadar çok farklı ilgi alanlarını da kapsayan derinlikli bir düşünce inşa etmeye çalışmıştır.

Deleuze felsefesi 20. Yüzyılın başında felsefede egemen olan özne felsefeleri, Hegel diyalektiği, yapısalcılık ve metafizik felsefelere karşı girişilmiş bir çabayı içerir. $O$, Husserl sonrası özne felsefelerini eleştirmiştir. Alman idealizminden beslenen özne felsefesi fenomonolojik yöntemle özneyi yeniden felsefenin gündemine getirmiştir. Husserl'in geliştirmiş olduğu fenomenolojik yöntem kendisini analitik felsefe veya pozitivizm karşıtlı̆̆ üzerine kurgulamıştır. Transandantal (aşkın) bir fenomenoloji geliştirmeye çalışmıştır. Husserl'in ana eleştiri konusu; doğa bilimlerinin nesneler veya olgular dışında bir tin (ruh, manevi) bir dünya kabul etmemiş olmasıdır. Bütün doğal ve manevi fenomenleri doğa bilimlerinin 
yöntemleri ile açıklama yoluna gidilmiştir. $\mathrm{Bu}$ ise büsbütün hatalı sonuçlara ulaşılmasına yol açmıştır.

Deluze, ontolojik ve epistemolojik olarak cogito'nun nasıl kodlandığını, özerkliğini nasıl yitirdiğini dile getirmiştir. Deleuze'ün arkadaşlarından Foucault başta olmak üzere Fransız postyapısalcığı öznenin iktidar tarafından nasıl oluşturulduğu/belirlendiğini göstermeye çalışmıştır. Okul, hapishane, kışla ve hastane üzerinden işleyen ve amacı "normalleştirme" olan modern iktidar hem makro hem de mikro olarak siyasetten ekonomiye, kültür ve eğitim politikalarından gündelik hayatın tekil örneklerine kadar özneyi kodlamaktadır. Söylemleri belirleyerek, dili manipüle ederek ve denetimi normalleştirerek insanların ruhları üzerinden işlemektedir. Yaşamı olumlayan modern iktidar çalışma, üretim ve sağlık politikalarına dayanmaktadır. Bu buluş kapitalizmin insan bedenleri üzerinden işlemesini sağlamıştır.

Deleuze felsefesi özne felsefeleri yanında Hegel diyalektiğinin de eleştiridir. 20. yüzyılın ilk yarısında Fransa'da A. Kojeve'nin Hegel okumaları felsefede yeni bir açılım sağlamıştır. J. Lacan'ın yapısalcı psikanalizi buradan beslenmiştir. Bu okuma diyalektik bir mücadeleye dayanır. $\mathrm{Bu}$ durum daima yapısal karşıtlıklar üzerine kuruludur. Bu karşıtlıklar arasındaki mücadele, gelişme ve ilerlemenin temelini oluşturur. Fakat Deleuze diyalektikten hoşlanmaz. Onun için diyalektik sürekli karşıtlıklar üretmekte ve daima birini öbürüne bağlamaktadır. (Tıpkı siyahın beyaza, kadının erkeğe, Doğu'nun Batı'ya dayanmak zorunda olması gibi.) Deleuze, bu ikiliği (düalizmi) aşmaya çalışmıştır.

Onun karşı çıtığı diğer bir felsefi düşünce metafizik felsefelerdir. Onun felsefi çizgisinin özünde Hume ve ampirizm yer alır. Onun ilham aldığ1 isimlerin ortak özelliği materyalist olmalarıdır. Hume, Nietzsche, Marks gibi. Ona göre Sokrates sonrası felsefe yaşamın yerine düşünceyi koymuştur. Yani Platon idealizmi ile yaşam daha üst bir nedene dayandırılmıştır. Oysa Deleuze için böyle üst bir erek yoktur. Onun bu düşünceleri Spinoza analizinde de görülür. Spinoza'ya göre bir eylem kendi başına iyi veya kötü değildir. İnsanı geliştiren eylemler iyi, geliştirmeyen ise kötüdür (Deleuze, 2011, s.28-29). Tıpkı Nietzsche'nin güç istencinde olduğu gibi. Deleuze düşüncesinde "arzu" önemli bir yer tutar. Arzuyu Nietzsche'ci bir okuma ile ele alan Deleuze, arzuyu öldürmeye çalışan metafizik felsefeleri eleştirmiştir. Onun felsefi 
düşüncesinde "beden”, “arzu”, "istenç” (irade) merkezi bir tutar. Deleuze insanı arzulayan makineler olarak tanımlamıştır.

Deleuze'ün felsefi düşüncesi Spinoza, Hume, Kant, Nietzsche, Bergson okumalarına dayalıdır. Fakat bu filozofları klasik bir biçimde bir yapı veya bütünlüklü bir felsefi sistem kurmak için ele almamıştır. Bu filozoflarla teması onun aradığı soruların yanıtlarını bulma amacını taşır. Sadece ilgisini çeken konuları/düşünceleri ele almıştır. Her filozofun felsefi düşüncesinde kendi "yaratıcı çokluk" ve "oluş"a dayalı felsefesini kurmak için yararlanmıştır.

Deleuze'ün düşünceleri 1968 sonrası Fransa'daki siyasal hareketlerin yeniden okunmasına dayanır. Klasik temsil mekanizmasına dayalı hiyerarşi üreten siyasal hareketlerin itibar kaybına uğradığı bu dönemde temsil ilişkisini reddeden, bunun yerine bir bütünlük, tamlığa dayanmayan, yaratıcı bir çokluğun içerimlendiği yeni bir eylem felsefesi geliştirmeye çalışmıştır. Böylece ele geçirilip kodlanan beden, cinsiyet, sınıf gibi kavramlara karşı yersizyurdsuz bir direniş mümkün olabilecektir. Sürekli hareket halinde olan bu çokluklar devlet, kapitalizm, piyasa tarafından ele geçirilemeyecektir. Tıpkı 1968 eylemlerinin herhangi bir hiyerarşi etrafında örgütlenmeyip, tamamen spontane gelişen bir eylem biçimi olması gibi. Böylece kodlanmış bedenler, denetim altına alınmış toplum, ikili karşıtlıklar içinde ele geçirilen cinsiyete karşı her biri diğeriyle iletişime geçen fakat kendi bağımsız tekilliğini koruyabilen köksaplar meydana gelebilecektir.

Bu çalışmada Deleuze'ün yaratıcı çokluk, oluş felsefesi, nomadoloji, köksap gibi kavramlar çerçevesinde incelenmesi amaçlanmıştır. Onun ikili karşıtlıkların yapıbozumuna (deconstruction) dayalı fikirlerinin postliberal ve sibernetik toplumla ilişkisi ve bu yeni toplumsallığın olanakları üzerinden bir analiz yapılması hedeflenmiştir. Deleuze düşüncesi ve temel kavramları söylem analizi ile incelenmeye çalışılmıştır. İlk başlık altında onun felsefesinin genel bir değerlendirilmesi, ikinci bölümde onun inşa ettiği temel kavramlar üçüncü bölümde ise ağ toplumu, küreselleşme ve postkapitalist sermaye hareketine Deleuze'ün bakış açısı yorumlanmaya çalışılmıştır. 


\section{Deleuze Düşüncesinin Felsefi Temelleri}

Deleuze 1925 yılında Paris'te doğmuştur. 1944-48 yılları arasında ise Sorbonne Üniversitesinde felsefe okumuş, 1948 yllında felsefe öğretmenliği yapmaya başlamıştır. 1957'de Sorbonne üniversitesinde asistanlığa başlamıştır. 1960-64 yılları arasında ise Fransız araştırma şirketi C.N.R.S.'de araştırma yapmaya hak kazanmıştır. 1962 yılında Michel Foucault ile sonrasında ise 1969 yılında birlikte Felix Guittari ile tanışmıştır. $\mathrm{Bu}$ ikilinin dostluğu çok verimli, sembiyotik bir ilişkinin doğmasını sağlamıştır. Eyleme dönük yüzü ile Guittari ve kuramsal ağırlıklı çalışan Deleuze, birlikte tek bir kişi gibi bütünleşerek eserler üretmişlerdir. Bir tür yaratıcı çokluk oluşturmuşlardır. Birey imgesini aşarak iki bedende tek bir zihin olarak işlemişlerdir. "Deleuze oldukça yoğun bir şekilde kavramlarla çalışmakta, Guittari ise "arzulanan makinalar" kavramını geliştirmekteydi: Şizofrenik makinasal bir bilinçdışı söz konusu edilmekteydi (Akay, 1996a, s.15). Anti-Oidipus eseri bu birlikte çalışmanın en önemli ürünüdür. Organsız beden, kapma aygıtı, arzu üretimi, şizoanaliz, yersizyurdsuzlaşma, kodlama ve kod çözümü gibi pek çok kavramı literatüre sokan bu eser, Lacan'cı psikanalize yönelik de bir eleştiridir. Bu kitabı ikinci kitap olan "Bin Yayla" izlemiştir. Deleuze ve Guittari Paris VIII üniversitesinde birlikte dersler vermiştir. Sürekli solunum yetmezliği ve nefes darlığı çeken Deleuze, 1995 yılında intihar ederek yaşamina son vermiştir.

Deleuze önce felsefe tarihi ile ilgilenmiştir. Deleuze'ün felsefe tarihinde ilgisini çeken filozofların hemen tümünün ortak özelliği felsefe tarihinden kaçmış olmalarıdır. Deleuze'ün ilgisini çekmiş olan filozofların başında Hume, Bergson, Nietzsche, Leibniz ve en çok da Spinoza gelmektedir. Onun ilgisini çeken filozofların genel özelliği ampirist ve metafizik karşıtı olmalarıdır. Nietzsche'nin yaşamı olumlayan felsefesi, Spinoza'da bedenin olanakları, Hume'un ampirist epistemolojisi ve Bergson'un oluş felsefesi dikkatini çekmiştir. $\mathrm{O}$, bir filozofu analiz ederken bütünlüklü bir okuma yapmak yerine onların kendi düşüncesini destekleyen yanlarıyla ilgilenmiştir. Nitekim Deleuze'ün felsefe tarihi üzerine yazdığı yazılara bakıldığında, bunların tümünün de felsefe tarihi yapmaktan çok yaratmak, "felsefece bir yerbilgisi" oluşturmak amacı doğrultusunda kaleme alındıkları daha ilk bakışta anlaşılmaktadır. Bu teknikte tek başına hiçbir 
filozofun düşüncesinin model olarak alınmasına izin yoktur. Deleuze bunu gerçekleştirmek için felsefe metinlerinin gerisindeki ilk ilkeleri aramak yerine, felsefe tarihine yaklaşırken olduğu gibi her özgül felsefeye de ortasından yaklaşmıştır (Deleuze, 1990, s.31).

Soysal'a göre Deleuze ilk başta D. Hume'a yönelmiş, sonra da Nietzsche ve Spinoza' da karar kılmıştır. Bu okumaya Kant, Bergson ve Leibniz de eklenebilir. Deleuze Nietzsche felsefesinde yaşamı olumlamayı, oluşu, çoğulu, rastlantıyı bulmuştur. Başı olmayan dönüş ve güç istenci onun dikkatini çekmiştir (Soysal, 1996, s.23). Deleuze, kendini 1950 sonrası Husserl, Heidegger ve Kojeve'nin Hegel okumalarından başka bir yerde konumlandırmak istemiştir. Yeni bir Nietzsche okuması yapmayı denemiştir. "Deleuze'ü çeken, edebiyat ve sanatta yaşamsal deneyi düşünsel deneylemeyle özdeşleştiren; duyumsal güçler arasında, belleksel nitelikler arasında kurgular oluşturmaya çabalayan; tek bir kimliğin dağıldığı bir çoğul oluşlar ortamı dile getiren kişiliklerdir. Deleuze'ün düşüncesinin birlik ve bütünlüğe karşı bir düşünce olduğu söylenebilir. Siyasal anlayışı da bu esastan kaynaklanmaktadır." (Soysal, 1996, s.24).

Deleuze felsefesi materyalist ve aşkın (transendantal) felsefelere karşı içkin (imanent) bir felsefedir. Onun felsefe tarihinde ilgisini çeken filozoflardan biri D. Hume olmuştur. Deleuze'e göre Hume, bir insan bilimi kurmayı amaçlamıştır. Bunu da insan zihninin psikolojisi üzerine kurmaya çalışmıştır. Onun için önemli olan zihnin psikolojisi, zihnin duygulanımlarının psikolojisidir. (Deleuze, 2008, s.7).

Deleuze, Hume felsefesindeki deneyim kavramına dikkat çekmiştir. Ona göre ampirist felsefe "ayrık algıların bir topluluğu, hareketli bir art arda gelişi deneyiminden yola çıar." (Deleuze, 2008, s.88). Hume'a göre deneyimi ortaya çıaran şey farktır. Farklı olan şey deneyimlenir. Hume felsefesi bir töz felsefesi eleştirisidir. Bütün bilgiyi deneyimlere bağlar. Deneyimler dışında ayrı bir varlık yoktur. Bir de bunları birleştiren çağrışım yasaları vardır. Bitişiklik, benzerlik ve nedensellik. Çağrışım ilkeleri yoluyla karmaşık ideler meydana gelir.

Hume'un kişisel deneyimlerin art arda gelişi ve fark kavramını alan Deleuze, bir başka materyalist filozof Nietzsche'ye yönelmiştir. Deleuze'e göre Nietzsche'nin Batı felsefe tarihi açısından önemi, onun değerleri bir sorun olarak ele alması ve değerlerin eleştirisini yapmış olmasıydı. Bu 
yönüyle de çağdaş felsefe büyük ölçüde Nietzsche'den beslenmişti. Nietzsche mevcut değerlerin dökümünü yapıp onları eleştiriden uzak tutan Kant ve Schopenhaur ile mücadele etmiştir (Deleuze, 2000, s.2-3).

Deleuze, Nietzsche felsefesinde anlam üzerinde durmuştur. Anlamın tarihsel olarak güç ilişkilerinden bağımsız ele alınamayacağını belirtmiştir. Tarih, anlamların değişmesidir. Ona göre her egemenlik ve her boyun eğdirme yeni bir anlam demektir. Deleuze'e göre Nietzsche felsefesinin özünde "çokluk" yer alır. "Nietzsche'nin felsefesi, özündeki çokçuluk göz önünde bulundurulmadan anlaşlamaz ve doğrusunu söylemek gerekirse çokçuluk bir diğer türlü de görgücülük felsefenin kendisiyle bir gibidir. Çokçuluk, felsefenin icat ettiği tam da felsefeye özgü düşünce biçimidir... Bir olay, bir görüngü, bir kelime ve ne de bir düşünce yoktur ki çok anlamlı olmasın." (Deleuze, 2000, s.6). Ona göre her anlam öncekilerden izler taşır. "Tekin ayrılmaz görünümü, özsel başkalaşımı, değişmez semptomu: "Çoklu". Çoklu, tekin olumlaması, oluş da varlığın olumlaması. Oluşun olumlaması bizzat varlıktır, çoklunun olumlaması da tekin ta kendisidir, çoklu olumlama tekin olumlanma tarzıdır. "Tek, çokludur" (Deleuze, 2000, s.35).

Deleuze göre Nietzsche'nin soykütüksel analizi bir istenç (irade) felsefesidir. İstenç yani kuvvet nesnenin kendisi, dış görünümüdür. Her nesneyi birden fazla kuvvet etkiler. Kuvvet çoğuldur. Nietzsche düşüncesinde her kuvvet başka bir kuvvetle ilişki içerisindedir. Kuvvetin adı da istençtir. Her istenç kendini başka bir istenç üzerinde gerçekleştirir. Onun istenç felsefesinin Hegel gibi bir diyalektiğe dayanmadığını belirten Deleuze, Nietzsche'nin bir antidiyalektikçi olduğunu belirtmiştir. Hegelci diyalektikte olduğu gibi bir olumsuzlama Nietzsche'de görülmez. Onda diyalektiğin yerini ayrım almıştır. Yani aslında Nietzsche kendinde bir şeyi olumlu ve olumsuz olarak görmez. Onu süreç içinde etkiyen bir kuvvet olarak ele alır.

Deleuze'e göre Nietzsche felsefesinin bir diğer önemli yanı yaşamı olumlamasıdır. Bunu da Apollon ve Dionysos arasındaki karşıtlıkta dile getirmiştir. Dionysos yaşamı olumlayan bir Tanrıdır. "İlki kesinkes Dionysos'un olumlayıcı niteliği, yaşamın üst çözümü veya doğrulaması yerine yaşamın olumlaması." (Deleuze, 2000, s.19). Deleuze Sokrates sonrası Yunan felsefesini yaşamın yerine düşünceyi koymakla eleştirmiştir. Arzu kavramı küçümsenmiş, insan bedeni yok sayılmıştır. 
Deleuze'ün dikkatini çekmiş filozoflardan biri de Spinoza'dır. Ona göre felsefe tarihinde Spinoza kadar hem değerli bulunup hem de aşağılanıp, nefret edilen başka bir filozof yoktur. Deleuze'e göre Spinoza'nın temel görüşlerinden biri bedeni ve yaşamsallığı öne çıarmış olmasıdır. "Biz bedenin neler yapabileceğini bilmiyoruz... O, zihne beden karşısında öncelik veren yaklaşımı reddetmiştir. Bu ikisini birlikte hareket eden yapılar olarak görmüştür" (Deleuze, 2011, s.22).

Deleuze'e göre Spinoza düşüncesinde bir bilinç başka bir bilinçle karşılaştığında bu ikisi daha yüksek bir bağıntı oluşturur bazen de birlikteliği bozar. Doğanın düzeni birleşme ve dağılma düzenidir. "Bizler bilinçli varlıklar olarak bu birleşme ve dağılmaların etkileri dışında hiçbir şeyi kavrayamayız." (Deleuze, 2011, s.23). Bu düşünce Deleuze'ün köksap kavramını geliştirirken Spinoza'dan yararlandığını göstermektedir. Köksap kavramı da yaratıcı bir çokluk oluşturmayı amaçlar.

Deleuze Spinoza'nın bilinci önceleyen düşünceler karşı çıtığını ve bilincin duygular, itkiler çerçevesinde duygulanımda bulunan pasif bir yapı olduğunu belirtmiştir. Spinoza felsefesinde karşılaşmalar önemli yer tutar. Bu karşılaşmalar bilinci geliştirir ve onu yeni ve üst bir benliğe ulaştırır. Deleuze'e göre Spinoza düşüncesinde iyi ve kötü kavramlarının yerini insanı geliştiren veya onu engelleyen şeyler alır. "Demek ki, her zaman için doğanın ebedi yasalarına göre, kendilerine özgü düzenlerine göre birleşime giren ilişkiler vardır. İyi, bir cismin kendi ilişkilerini, gücünün tamamı ya da bir parçası ile, bizimki ile doğrudan birleştirmesi ve gücümüzü arttırmasıdır... Sonuç olarak, iyi ve kötü, insanın iki tür, iki kip varoluşunu niteleyen öznel ve kipsel olan ikinci bir anlama sahiptir." (Deleuze, 2011, s.28-29).

Spinoza etiği aşkın bir varlığa gönderme yapan ahlaktan farklıdır. $\mathrm{O}$, içkindir ve aşkın bir varlığa gönderme yapmaz (Spinoza, 2011). Deleuze'e göre Spinoza felsefesi bizi aşkın bir gerçekliğe veya değerlere bağlamaya çalışmaz. Spinoza düşüncesinde insanı geliştiren şey iyidir. Deleuze'e göre bedende etkin ve tepkin kuvvetler vardır. "Bir bedendeki üst veya hükmeden kuvvetler etkin, ast veya hükmedilen kuvvetler tepkindir. Etkin ve tepkin, bir kuvvetin diğer bir kuvvetle olan ilişkisini ifade eden kökensel birer niteliktir. Zira her birinin kendi nicelik ayrımına uygun düşen niteliği olmadıkça, ilişkiye giren kuvvetlerin bir niteliği yoktur." (Deleuze, 2000, s.58). 
Deleuze'e göre ast kuvvetler tepkin olarak tanımlanabilir. Mekanizma ve erekler sağlayarak, koruma ve uyum sağlarlar. Oysa etkin kuvvetler gücü oluşturur. Hükmeder, etki eder, yönlendirir. Bu pasif kuvvetlerle aktif kuvvetler arasındaki farkı gösterir. Yaşama hükmeden değerler ve kuvvetler etkin, pasif kalanlar ise tepkindir. Tepkin kuvvetler olumsuzlayıcı, etkin kuvvetleri ise olumlayıcıdır. "Etkin kuvvetler soyludurlar ama tepkin kuvvetlerden yansiyan plebce bir imgenin karşısında bulurlar kendilerini. Soykütük ayrım veya ayırt etme sanatıdır, soyluluk sanatıdır ama tepkin kuvvetlerin aynasında bu tersten görünür." (Deleuze, 2000, s.80).

Deleuze'ün felsefi düşüncelerini biçimlendirirken yararlandığ 1 isimlerden biri de H. Bergson'dur. Deleuze'ü Bergson'a yönlendiren şey, onun statik olana değil dinamik varoluşa yönelmiş olmasıdır. Statik olan (dil, yapılar, sistem) kolayca denetim altına alınıp, içerimlenebilir. Oysa dinamik olanlar, yaratıcı bilinç sürekli bir akış içerisindedir. Öngörülemez biçimlerle yeni yaşam formlarını ortaya koyabilir. Denetimden kaçabilir. Kendini var edebilir. Bergson felsefesinde sezgi bunu yapabilen yetidir.

Bergson felsefesi sistem kuran filozoflara yönelik bir eleştiridir. Bu eleştirinin nedeni, geliştirilen kavramların gerçek dünyaya "bol gelmesidir." Yani kavramlar somut dünyayı sskalamaktadır. Bu nedenle felsefe soyut, spekülatif kurgularla ilgilenmek yerine doğruluğa yönelilmelidir. Doğruluk ise hayatın içindeki gerçek problemler, hayatın akışıdır (Bergson, 2011). “Oysa Bergson için, hiçbir gerçeklik başka bir gerçeklikten düşünceyle türetilemez; dünyanın birliğe sahip olup olmadığını yalnızca deneyim gösterir. Yeni problemler gerçekten de vardır ve filozof her yeni problem karşısında o probleme özgü çözümleri araştırmak zorundadır." (Deleuze, 2006, s.14).

Bergson'un sezgiye dayalı felsefi düşüncesi dolaysız kavrananların bilgisidir. Soyut ve belirsizliklerine yerine somut ve deneyimlere dayanir. Bu deneyimler önceki deneyimlere eklenerek sürdürülür. Hegel diyalektiği tek yönlü bir gelişme çizgisi ortaya koyarken Bergson'da gelişme önceden belirlenemez ve tek yönlü değildir. "Bergsoncu sezgi, gerçek tekil deneyimin koşullarının peşindedir." (Deleuze, 2006, s.21).

Deleuze'e göre Bergson felsefesindeki "süre" kavramı bir çokluk yaratır fakat bu çokluk niceliksel bir çokluktan farklıdır. "Buna karşlık, süreyi ya da öznelliği tanımlayan sayısal olmayan çokluk artık uzaysal 
olmayan, tümüyle zamansal bir başka boyuta dâhil olur: Virtüel olandan bunun edimselleşmesine gider, kendi doğa farklarına karşılık gelen farklılaşma çizgileri yaratarak edimselleşir. Böyle bir çokluk, özünde, süreklilik, heterojenlik ve yalınlık özelliklerini taşır. Ve burada, Bergson için, heterojenlikle sürekliliği uzlaştırmada gerçekten de hiçbir güçlük yoktur." (Deleuze, 2006, s.83).

Deleuze, Bergson'daki bellek kavramına da vurgu yapmıştır. Bellek Bergson'a göre yaşayan bilinçtir. Süreyi doğrudan kavrayan bilincin edimidir. Bellek aynı zamanda geçmiş deneyimleri şu ana transfer eder. Bu sayede geçmiş bugünde yaşanır. Bu ise düşünceye yaratıcı bir oluş ve dirimsellik katar. Aynı zamanda düşünce yoğunlaşır ve belirli bir noktada gelişme gösterir. Bu bir tür yaşanılan deneyimlerin birikmesi ve ortak bir üretime dönüşmesi gibidir.

Özetle Deleuze felsefesi diyalektik, hümanist ve metafizik felsefelere karşı yaratıcı bir oluşu, yaşamın olumlanması ve güç istencini merkeze alan bir felsefedir. Bütünlük yerine farka vurgu yapar. Hayatı daha yüce bir amaca dayandırmadan insanı geliştiren eylemlere yönelir. Birbirine bağlanan çoğulluklar ve yaşamın dinamik enerjisi bedenin olanakları ile birleşir. Kartezyen veya diyalektik bir çatışmaya değil yeni bağlantılarla köksaplar oluşturan, sabitlenemeyen ve belirli bir mekana hapsedilmeyen ve kodlanamayan eylemselliklere dayalıdır. Onun felsefesi ürettiği kavramları da bu yeni anlamlarla zenginleştirmesini sağlamıştır.

\section{Deleuze Felsefesinde Temel Kavramlar}

Deleuze felsefesini ayırt eden temel niteliklerin başında onun yaratmış olduğu kavramlar gelir. Bu kavramlar onun izlerini taşır. Savaş makinesi, kapma aygıtı, göçebebilim, yersizyurdsuzlaşma, arzu makinesi, organsız beden, şizoanaliz, köksap gibi. Bunların bir kısmını F. Guittari ile birlikte geliştirmişlerdir. Bu ikilinin birlikte yazdığı kitapların en önemlileri "Anti Oedipus" ve "Bin Yayla"dır.

Deleuze ve Guittari, Anti-Oepdipus kitabının başında devletle göçebeleri karşılaştırmıştır. Belirli bir yere sabitlemeye çalışan devlet aygıtı (kapma aygıtı) ile bir yere sabitlenmek istemeyen göçebeler arasındaki ilişkiyi Hint Avrupa mitolojisinden yola çıkarak ele almışlardır. Onlara göre Hint Avrupa mitolojilerinde hükümdarlık iki başlıdır. Büyücü 
kral ve hukukçu-papazın politik egemenliği. Bu iki ayrı kutup birbirlerine karşıt görünseler de birbirilerini tamamlarlar. İkisi hem birbirinin düşmanı hem de birbirinin tamamlayıcısıdır. Devletin sahip olduğu şiddet insanları yakalar ve sabitler. Onun polisi ve gardiyanları vardır. Büyüsel bir kapma ile hareket eder. Her çeşit kavgayı önler, yakalar ve bağlar. Göçebeleri tanımlamak için "savaş makinesi" kavramını kullanan Deleuze ve Guittari'ye göre savaş makinası, devlet aygıtına indirgenemez. Onun egemenliğinin dışındadır (Deleuze ve Guittari, 1990, s.25-26).

Deleuze ve Guittari devlet aygitı ve savaş makinesini iki farklı oyun üzerinden karşılaştırır. Onlara göre satranç oyunu devleti örnekler. Oradaki her bir piyon bir asker, bir at bir süvaridir. Satrançta belirli biçimde kodlanmış ve konumu diğerine göre değişen bir sistematik vardır. Oysa go oyunu böyle değildir. Onun piyonları tane tanedir ve pastildir, bir üçüncü şahıstır. Herhangi bir kişi veya bedeni temsil etmezler. "O ilerler, bu bir erkek, bir kadın, bir pire, bir fil olabilir. Go'nun piyonları özneleşmemiş bir makinasal düzenlemenin ögeleridir; onların iç özellikleri yoktur, sadece durumları vardır." (Deleuze ve Guittari, 1990, s.27). Satranç kodlanmış, belirlenmiş, kurumsallaşmış bir savaşı temsil eder. Satrançta en az taşla bir alanı ele geçirmek önemlidir. Go oyununda ise bir mekandan başka bir mekana gidiş, ani saldırılar vardır. Mekanı tutmak, bir mekandan başka bir mekana geçiş yapmak gerekebilir. Go'nun kaygan mekanının karşıtı satrancın pürtüklü mekanıdır. Devletin satrancının karşısında Go'nun yasası (nomusu) vardır. Satranç mekanı kodlar ve koddan çıkarır. Go ise mekanı başka türlü ele alır. Mekanı yersizyurdsuzlaştırır.

Yersizyurdsuzlaşma ve göçebe oluş Deleuze düşüncesinin ana eksenini oluşturur. Onun göçebeliğe verdiği önem kapitalizm gibi sistemler tarafından kodlanıp ele geçirilememesidir. Göçebe sürekli yer değiştirir. Onun için bir su yolu, bir dağ, bir vadi ancak bir işarettir. Ama her zaman her şey işaret olabilir. $O$, göçmen gibi bir yere yerleşmek ve orayı yurt edinmek üzere hareket etmez. Onun yolu tanımlanmamış, belirlenmemiş, işaretlenmemiştir. Onun mekânı pürtüksüz ve kaygandır. Onun üleştirmesi, paylaştırması da yerleşikten farklıdır. Her şey dağıtılmak içindir. Etrafı çitle çevrilmemiş, sahiplenip ele geçirilmemiş mekânda yaşar. "Yerleşiklerin mekânı duvarlarla, çitlerle, çitler arasındaki yollarla çevrilidir, mekanı pürtüklüdür, halbuki göçebenin mekanı 
yalnızca çizgilerle işaretlenmiş kaygan mekandır. Çölün şeritleri bile taklit edilemeyen bir ses çıkarıp, birbirleri üzerinden kayarlar. Göçebenin dağıtım yaptığ1 yer kaygan mekandır, göçebe işgal eder, oturur, bu mekânı tutar ve göçebenin sadece bu şekilde bir yurd mevhumu vardır." (Deleuze ve Guittari, 1990, s. 82).

Onlara göre göçebeler yasadan kaçarlar. Yasanın onları sabitlemesinden hoşlanmazlar. Devlet ise mekanı pürtüklü hale getirip, insanları sabitlemeye, kaçış noktalarını kapatmaya çalışır. Devlet yapabildiği her alanda bir tür yakalama, içerme süreci içine girer. Onun bir dışarısı yoktur. Hızı sabitler, dolaşımı sınırlar, insanları izler ve kaydeder. Karayolu ağları, sınırlar denetlenir. İçeri sızmaya çalışanlara engel olur. "Bu bakımdan, devlet hareketi böler, yeniden toplayıp değiştirmekten veya hızı kurallaştırmaktan bıkmaz; gözetleyici, ikna edici veya yolları bekçisi olarak devlet vardır." (Deleuze ve Guittari, 1990, s.93).

Deleuze'e göre yersizyurdsuzlaşma tıpkı sermaye hareketi gibi belirli bir yere sabitlenmeyen, dinamik bir oluş sürecidir. $O$, bir çoğulluktur. Kendi hâkim kimliğinin içerisinde ötekini yerleştirmektir. Tek bir dille bile iki dilli olma durumudur. Kendi dilimizde bir azınlık yaratmaktır. Zorlama olmadan, doğal bir akış içerisinde gerçekleşir. İktidarın ortaya çıkmadığı bir durumdur (Deleuze, 2005, s.36). İki dil konuşan yazarlar bir dil içerisinde yabancı gibi konuşarak iki dilli olmaya başarabilir. Böylece bir dile sabitlenip kalmamakta ve dil üzerinden de işleyen iktidarın denetiminden kaçabilmektedir. Bu yeni çoğullukların ortaya çıkmasını da sağlamaktadır. Bu dilin yersizyurdsuzlaştırılmasıdır.

Deleuze, bedenlerin çizgilerden oluştuğunu söylemiştir. "Bireyler veya gruplar, biz aynı doğadan ve ritimden olmayan hazneler, dönenceler, geodesikler, meridyenler ve onların çizgilerince kat edilmişizdir. Bizi birleştirenler çizgilerdir, üç çeşit çizgi veya çizgiler paketi, çünkü her çeşit bir çokluktur. Şu veya bu çizgilerle ilgilenebilir ve belki de neticede, belirleyici olan değil, ama diğerlerinden daha önemli olan biri vardır..." (Deleuze ve Guittari, 1993, s.29). Çizgilerden oluşan insan bedeni kaçı̧̧ çizgileri sayesinde yeni ve yaratıcı sentezlere dönüşebilir veya tersi durumlarda daha katı bir durum da alabilir. "Kaçış çizgisi iki dize parçayı patlatır, ama daha da kötüsünü yapabilir, bir duvar üzerine sıçrayabilir, bir kara deliğe düşebilir, gerilemeye doğru giden yolu alabilir, dönüşlerin 
rastlantılarına göre en katı parçaları yeniden oluşturabilir." (Deleuze ve Guittari, 1993, s.33).

Deleuze ve Guittari bireysel moleküler çizgilerden, birbirinin tekilliğini ortadan kaldırmadan birbirine eklemlenen, bir köksap oluşturan bir yapıdan söz etmişlerdir. Bu sayede katılıktan, kapılmaktan ve sertlikten uzaklaşılıp denetim dışına çıkılabilecektir. Akış ve oluş çizgileri bir kapma aygitı olan devlet, kurumlar ve sinfflardan kurtulma amacındadır. "Artık sadece bir çizgiyimdir... Boşluğu kat eden bir ok gibi artık sadece soyut bir çizgi oluruz. Mutlak yersizyurdsuzlaşma. Artık kimsenin herkes gibi olmayacağı bir şekilde, herhangi biri gibi olunur." (Deleuze ve Guittari, 1993, s.25).

Deleuze'ün kaçış çizgileri, yersizyurdsuzlaşma ve göçebe oluşu kapitalizm gibi sistemler tarafından kodlanıp sabitlenen bedenlere yönelik bir çıkış yoludur. Kapitalizm insan bedeni üzerinden işlemekte, yaşamı olumlamakta ve insan enerjisini kapmaktadır. Deleuze'e göre kodlanmış beden imgesine karşı çıkış yolu "organsız beden"dir. Organsız beden, kaotik, anarşik bir oluşu ifade eden, üzerine kazınmış bütün sabit kimlikleri söküp atar. Hem erkek hem kadın kimliklerini dışlar. Böylece ikili karşıtlıklara dayalı cinsiyet, etnisite gibi bütün ayrımları ortadan kaldırır.

Deleuze ve Guattari'nin birlikte geliştirdikleri kavramlardan biri de "köksap"tır. Köksap, bir özneye ya da nesneye sabitlenebilen, ama buna karşın hiçbir birliği ve bütünlüğü olmayan bir çokluktur. Sabit bir düzeni olmayan köksaplar kolayca başka öznelerle bağlantıya geçebilir. Kırıldığı yerden yeniden sap verir. Bu bağlantılar sayesinde çoğullaşma ve yaratıcı oluşlar olanaklı olacaktır. "Çokluk $1+1+1$.... değil, n-1'dir... Köklerin çiftçatallanmasına, birbirlerine olan bağımlılğına, her alanı dilbilgisel boyuta indirgemelerine, nesnelerle anlamları arasında koydukları mesafeye göre, köksap birbirinden kopuk, dilbiliminden ayr1, siyasi, ekonomik, biyolojik anlamları içinde taşıyan ve kopukluğu sayesinde bir bütün oluşturamayan tekilliklerin birbirlerinden bağımsız ve çıkarma işlemiyle çıkmalarıyla (n-1) oluşur." (Deleuze ve Guittari, 1993, s.10).

Köksapların oluşması ile birlikte azınlık ve çoğunluk kavramları da anlamını yitirecektir. Farklı kimliklerin birbiri üzerinde iktidar oluşturması önlenebilecektir. Deleuze'e göre azınlık veya çoğunluk kavramları sadece nicel bir duruma göndermede bulunmazlar. Çoğu durumda çoğunluk 
normu, kuralı belirler. Ötekinden bu norma bağlanmasını bekler. Kendisini hak sahibi olarak belirledikten sonra ötekini bir sorun olarak algılar. Deleuze, çoğunluk veya azınlık kavramları yerine "oluş" kavramlarını yerleştirmiştir. "Çoğunluksal oluş yoktur, çoğunluk hiçbir zaman oluş değildir. Yanlızca azınlıksal oluş vardır. Kadınlar sayıları ne kadar olursa olsun, durum ya da alt beraberlik olarak tanımlanabilecek bir azınlıktır ama ancak sahipleri olmadıkları, kendilerinin de içeri girmesi gerektiği bir oluşu, tüm insanı- kadın olmayanlar da dahil- ilgilendiren bir kadın oluşu olanaklı kılarak yaratmaktadırlar. Zenciler için de durum aynıdır: Eğer zencilerin de zenci olmaları gerekiyorsa, bu oluş zenci olmayanları da etkiler." (Deleuze, 2006, s.69).

Deleuze bir psikiyatr olan Guittari'nin de çalışmaları ile psikanalize yönelik eleştirilerde de bulunur. Onların psikanalize karşı ürettikleri kavram şizoanalizdir. Bu klasik bir psikanaliz eleştirisinden çok Lacancı bir psikanalizin eleştirisi olarak görülebilir. Yapısalcı bir psikanaliz geliştirmeye çalışan Lacan, Hegel'in Kojeve okumalarından yola çıkarak her kimliğin öteki dolayımında ve öteki sayesinde inşa edildiğini savunmuştur. "Ayna Benlik" teorisi ile de "imgesel, simgesel ve gerçek" dönemlerinden söz etmiştir. Bilinçdışının dili gibi yapılandığını belirterek, bilinçdışının çözümlemesine girişmiştir. Yapısalcılığın sistem/yapı analizleri gibi bilinçdışının da kültürden bağımsız ele alınmayacağını ve aslında bilinçdışının büyük ölçüde simgesel düzlemde öteki üzerinden gerçekleştiğini belirtmiştir.

Hegel diyalektiğinden ve yapısalcılığın sistem lehine yaptığı düzenlemelerden memnun olmayan Deleuze, şizoanalizle hem bir klasik ve Lacancı psikanaliz hem de bir kapitalizm eleştirisi yapmaya çalışmıştır. Kapitalizm bireyleri kodlamakta ve onları üretim sürecinin bir parçası haline getirmektedir. Şizo (şizofren) kodlanamayan, kodlanmaktan kaçabilen kişidir. Freud'un başarısı psikanaliz sayesinde nevrozları kabul edilebilir bir hastalık kategorisine eklemesidir. Böylece hafif rahatsızlıklar olarak görülen nevrozlar kapitalizm tarafından içerilmiştir. Fakat psikozlar denetim dışıdır. Onlar kodlanamayan bedenlerdir. Kodlardan ve denetimden kaçmaktadır. Bir tür devrimcidirler. Kapma aygıtı olan devlet kâra, verimliliğe, pazarlama ve reklam endüstrisine dayanır. Şizofrenin devrimciliği kapitalist kodları bozucu bir etki göstermesidir. 
Holland'a göre kapitalizm inanç ve değerlerin yerine nakit akışı koyarak insanları şizofreniye yaklaştırır. Sermayenin yayılımı ve onun psikolojik yönelimi süreğen bir şizofreni tutumu meydana getirir. Paranoya insanları bir yere sabitlerken şizofreni bu bağı kaldırır ve insanı sabitlikten kurtarıp özgürleştirir. Bu psikolojik çöküntüden çok devrimci bir atılımdır (Holland, 2013, s.23-24).

Deleuze ve Guattari, Freud ve Marks'tan aldıkları "arzu”, "üretim" ve "makine" kavramlarını yeni bir psikanalist bakış açısıyla bir araya getirmişler ve insanların arzulayan makineler olduklarını söylemişlerdir. İnsanın özgürlüğü, arzu duyan bir hayvan olmasıyla eşdeğerdir. Hiyerarşi ve tabuları merkez alan ataerkil bir fallusçuluğu yadsırlar. İrdelenen "arzu" kavramına, psikanalizde "iktidar" kavramıla açıklık getirilmeye çalışılır. Ve bu bağlamda şizofrenik arzu istencini, Nietzscheci iktidar istenci ile bir tutarlar (Akay, 1991:54).

Deleuze'e göre psikanaliz, bütün arzu üretimini kırmaktadır, tüm söylenen oluşumları ezmektedir. Böylece de kolektif anlatım düzenlemesini, arzunun makinesel düzenlemesini, iki yüzünden birden düzenlemeyi kırıp parçalamaktadır. Psikanaliz için arzular gereğinden fazladır. Daima bir şey başka bir şeyi hatırlatmak zorundadır. Deleuze'de bilinçdışı Freudçü analizin tersine çocukluk dönemine ait değil geleceğe dönüktür. Bilinçdışı üretilen, akıtılan, istila edilmesi gereken politik, sosyal bir uzam bir tözdür (Deleuze, 1990) Deleuze'ün psikanalize bir başka eleştirisi de psikanalizin insanların konuşmaların önlemek ve onlardan gerçek anlatım şartlarının tümünü birden çekip almak için yapılmış olduğudur.

Deleuze'e göre ileri kapitalizmin yüksek hızlı toplumsal denetim özelliği, toplumsal kodların göreli sabitliği kitlesel üretimin belitleri için vazgeçilmez olduğu müddetçe, şizofrenik kodsuzlaştırma bozucu bir etkiye sahiptir. Ancak sibernetik mega makine yaşam tarzlarındaki en küçük değişiklikleri, döviz, hisse ve tahvil dalgalanmalarını neredeyse anında kapıp, kendi sistemine programlayabilecek güce eriştiğinde şizofreninin afallatıcı semiyotiği faydasız olacaktır (Holland, 2005, s.84).

Görüldüğü gibi Deleuze felsefesi birbirine eklemlenmiş kavramlar ve bu kavramların zengin içeriği ile ilişkilendirilerek anlaşılabilir. Onun kavramların nevi şahsına münhasırdır. Bu kavramlar aynı zamanda bir köksap oluşturacak biçimde birbirlerine bağlıdır. Şizo kapitalizmin arzu üretiminden ve denetiminden kaçmakta, organsız bedenler herhangi bir 
kodlamaya olanak tanımamaktadır. Kapitalizmin yükselişini sağlayan şeyin onun yıkımını da sağlayacağını düşünen Deleuze, arzuyu denetim altına almak yerine onu serbest bırakmayı tercih eder. Yaşamı bütün olanakları ile ele alır. Yaratıcı bir oluşu, yerini yurdunu terk ederek sürekli bir yersizyudsuzlaşmayı ele alır. Göçebeler mekanı yersizyurdsuzlaştırmaktadır. Bu şekilde çoğunluk-azınlık, kadın-erkek, siya-beyaz gibi bütün karşıtlıklar ve onun işlemesini sağlayan diyalektik de geçersiz olacaktır. Tekilliklerin bir çoğulluk üretmeden bir araya gelişi ve sistemin çarklarına karşı duruşudur.

\section{Deleuze Felsefesi ve Yeni Toplumsal Hareketler}

Deleuze'ün felsefi düşüncesinin gerisinde kodlayan, sabitleyen ve denetim altına alan sistemlere karşı bir arayış vardır. Kapitalizmin küresel bir biçim kazanması, transnasyonel sermayenin dünya üzerinde mobil hale gelmesi, çok uluslu şirketler ve küresel iktidarlara karşı siyasette yeni bir çıkış yolu arayışını gerektirmiştir (Nas, 2018, s.73). Deleuze felsefesi bu yeni duruma yönelik bir politik bir tutumdur. 1968 olaylarında kendini gösteren oluşlar (kadın oluş, zenci oluş, işçi oluş vb.) ortak bir eylem içinde bir köksap oluşturacak biçimde birlikte mücadele etmiştir.

1970 sonrası enformasyon teknolojilerine dayal1, Post-Fordist üretim biçiminin egemen olduğu, transnasyonel sermaye ağlarına dayalı yeni sosyoekonomik ve politik durumu sosyal bilimciler farklı kavramlarla analiz etmeye çalışmıştır. M. Castells enformasyona dayalı bu yeni toplum biçimine "ağ toplumu" adını vermiştir. Castellls (2008)'e göre enformasyon teknolojileri, küresel çapta bütünleşik bir piyasa düzeni oluşturmuştur. Kapitalizm bilgi ağları sayesinde daha esnek bir biçim almış, şirketler arasında yeni iş birliği olanakları ortaya çıkmıştır. Çalışma ilişkileri ve iş saatleri esnekleşmiştir.

Teknolojik alt yapının eşlik ettiği bu yeni toplum düzeni klasik işçiişveren ilişkilerini de dönüştürmüştür. İş hayatı üzerinde beyaz yakalıların etkisi artmıştır. Aynı zamanda klasik işçi hareketleri de anlamsızlaşmıştır. Temsil ilişkisi, sendikal hareketler eski gücünü yitirmiştir. "Emek performans itibariyle bütünlügünü yitirmiş, örgütlenmesi itibariyle parçalanmış, var oluşu itibariyle çeşitlilik gösterir hale gelmiş, kolektif eylem itibariyle bölünmüştür." (Castells, 2008: 628) 
Sermaye sahibi, üretici, emekçi, aracı giderek belirsizleşmektedir. Sermaye ve emek gittikçe dönüşüme uğramaktadır. Bu yeni dönemde kültürel semboller de artık bilgisayar ağları, medya kanalları vasıtasıyla aktarılabilen dijital göstergelere dönüşmüştür.

$\mathrm{Bu}$ yeni sosyoekonomik gelişmeleri yorumlayan sosyal bilimcilerden biri olan D. Bell bu yeni toplum biçimine "post-endüstriyel toplum" adını vermiştir. Bell; sanayi öncesi, sanayi toplumu ve sanayi sonrası toplu olmak üzere insanlığın geçirdiği ekonomik devrimleri üç farklı kavramlarla açıklamıştır. Ona emek yoğun ve doğal koşullara bağlı sanayi öncesi toplum biçiminde sanayi toplumuna geçilmiştir. Sanayi toplumu ile birlikte emeğin yerini makine gücü almaya başlamış, üretim süreci yeniden düzenlenmiştir. Sanayi sonrası toplumun dikkat çekici bazı özellikleri vardır. Bell'e göre bunlardan biri imalat sanayinden hizmet üretimine geçiştir. Sanayi toplumuna egemen olan sanayi üretimi, fabrika, kas gücü yerini hizmet sektörüne dayalı entelektüel emeğe (maddi olmayan emek) bırakmaya başlamıştır (Bell, 1973, s.15). Bu yeni dönemin en önemli sermayesi bilgidir. Sanayi öncesi dönemde toprağa bağlı rant, sanayi döneminde sermayenin sağlamış olduğu kâr yerini bilgi toplumunda hizmet üretimine bırakmıştır. Bilim insanları, teknik uzmanlar, üniversite, akademi ve teknokentlerin üretim üzerinde etkisi artmıştır.

Fütürolog A. Toffler ise Bell'e benzer biçimde üretim teknolojisinde üç farklı gelişmeden söz etmiştir. Yaşamakta olduğumuz döneme "Third Wave" (Üçüncü Dalga) adını vermiştir. Ona göre insanlık yeni bir devrimle karşı karşıyadır. Birinci dalga tarım devrimi, ikinci dalga sanayi devrimi, üçüncü dalga ise bilgi devrimidir (Toffler, 2008, s.15). Üçüncü dalga ile birlikte sadece üretimin yapısında değil toplumsal ve siyasal yapılarda da önemli değişimler yaşanmaktadır.

Hardt ve Negri ise 1970 sonrası belirgin bir değişme gösteren, enformasyon teknolojilerine dayalı yeni dönemi uluslararası ilişkiler ve siyaset bağlamında analiz etmiştir. Hardt ve Negri'ye bu yeni küresl düzenin adı "İmparatorluk"tur. İmparatorluk yer küre üzerinde, bir dışarısı olmayan, esnek komuta ağları sayesinde işleyen yeni siyasal yapıdır (Hardt ve Negri, 2008, s.14-15). Egemenliğin ulus devletlerden yeni küresel şirketlere geçmiş olması, ulus devletleri tamamen ortadan kaldırmamış fakat 
etkisizleştirmiştir. Yeni ortaya çıkan esnek yapılar kapitalizm ve iktidarların geniş bilgi ağları sayesinde etkileşime geçerek daha geniş bir alanda hükmetmesini sağlamıştır.

"Çokluk" kavramını da ele alan Hardt ve Negri bunun ne halk ne kitle ne de sınıfa karşılık geldiğini belirtmiştir. Onlara göre çokluk tekliğe indirgenemez. Çokluk tüm tekil farkların çoğulluğudur (Hardt ve Negri, 2004, s.12). Bu çokluk kavramı Deleuze'ün önermiş olduğu birbirine köksap olabilecek şekilde bağlanan yaratıcı bir çokluktur. Küresel ölçekte yaygınlık kazanan fakat ötekinin var oluşunu kendi var oluşu gibi önemseyen, bütünleşmemiş çokluklardır.

Deleuze'ün felsefi düşüncelerinden yola çlkarak "imparatorluk", "ağ toplumu", "sanayi sonrası toplum" veya "üçüncü dalga" gibi farklı isimlerle anılan yeni sosyo-siyasal, tekno-dijital düzende yeni toplumsal hareketler için nasıl bir çıkış yolu aranabilir? Deleuze'ün düşünsel çerçevesi bir ölçüde bunun serimlenmesidir. Deleuze bu yeni dönemde klasik sınıf, öğrenci, kadın veya diğer hareketlerin kolayca manipüle edilebildiğini, sistem tarafından kodlanarak hayatiyetini yitirdiğini düşünmektedir. Onun için çözüm tekillikler üzerinden yeni kaçış çizgileri ortaya çıkarmak, kültürden, cinsiyetten sıyrılmak, organsız bir beden olmaktır. Küre ölçeğinde yersizyurdsuzlaşmaktır. Bu dönemin temel özelliği majörün yerini minörün, sosyolojinin yerini sosyalliklerin almış olmasıdır. Parçalanmış, atomize olmuş bu yeni toplum yapısında bir bütün oluşturma amacını taşımadan farklı tekillikler üzerinden, yatay bir ilişki geliştirilmesini amaçlamıştır. Elbette bu çoklukların nasıl bir köksap oluşturacağı, kültür, inanç, dil gibi bütün farklılıkların yerine sadece oluşların nasıl eklemlenebileceği, küresel bir yer değiştirme ve yersizyurdsuzlaşmanın nasıl bir direnişe olanak tanıyacağı tartışmalıdır. Özellikle 11 Eylül sonrasında küresel düzlemde güçlenen ayrımcı, ötekileştirici hatta nefret taşıyan dil, milliyetçili politikalar bu yeni küresel direnişin olanaklarının altını oymaktadır.

1968 sonrası ortaya çıkan çoğulculuk bugün yerini toplumsal hareketlerin içerik değiştirmesine yol açmıştır. Etnik, dinsel ve kültürel farklar ve bunlar arasındaki çatışmalar yeniden gündeme gelmeye başlamış, savaş baronlarının dili siyasete egemen olmuştur. Fakat diğer taraftan sömürü ortadan kalkmamış, daha da artmıştır. İktidarların organize yapısı, sermayenin küresel ağlar çerçevesinde yayılış biçimi ve 
bütün bunları kolaylaştıran dijital dönüşüm sömürünün farklı biçimlerde süreceğini göstermektedir.

Deleuze'ün önermiş olduğu kavramların küresel toplumsal hareketler için ilham verici olduğu açıktır. Nitekim Hardt ve Negri gibi isimler bunun arayışı içindedir. Bu yeni küresel hareketler sosyal medya üzerinden iletişime geçen, bir iktidar içermeden örgütlenmiş, farklı siyasal, etnik, kültürel, ekonomik taleplere odaklanmış yapılardır. Kimsenin kendi tekilliğini ortadan kaldırmadan fakat aynı zamanda bir çoğunluk veya azınlık durumu da yaratmadan ortaya çıkabilecek bir durumdur. Sistem tarafından kodlanamayan, sürekli yer değiştiren, yersizyurdsuzlaştıran bir direniş sistemin ölümünü de hızlandıracaktır. Foucault'nun dediği gibi iktidar her yerde ise direniş de her yerdedir. İktidarlara karşı direnişin de yeni durumu doğru okuyarak buna uygun olarak gardını alması gerekir. Deleuze felsefesi buna yönelik bir çıkış yolu arayışıdır.

\section{Sonuç}

G. Deleuze'ün felsefi düşünceleri sosyoloji, siyaset, ekonomi, sinema, psikiyatri, tıp gibi çeşitli alanlara katkı sağlamıştır. Onun felsefesi kavramsal bir seremoniyi andırır. Kavram üretimini felsefe yapmanın odağına yerleştiren Deleuze mistik/metafizik felsefelere karşı Nietzsche, Spinoza ve Marks bağlamında bir felsefi söylem geliştirmiştir. Nietzsche'den yaşamı olumlama, bengi dönüş ve güç istenci kavramlarını alan Deleuze, Spinoza'da ise bedenin olanaklarını bulmuştur. Marks'ın yaratıcı emek kavramından yola çkarak post-kapitalist üretim sürecine yönelik yeni saptamalar yapmaya çalışmıştır. İnsanları arzu makinesine benzeten Deleuze, insanın arzu duymasını negatif bir durum olarak değil yaşamın amacı olarak görmüştür. Lacancı psikanalizi eleştirmiştir. Oluşun felsefesini yapmak için de Bergson'dan yararlanmıştır.

Deleuze felsefesi organsız bedenler, göçebebilim, köksap, arzu makinesi, şizoanaliz gibi zengin ve tematik kavramlara dayanır. Bu kavramlar homojenleştirici ulus politikalarına karşıdır. Postmodern dönemle birlikte hakikatin çoğullaşması, meta anlatıların ölümü, tek bir hakikat olmadığı düşüncesinin güçlenmesini sağlamıştır. Bu çoğullaşma sınıf, etnisite, din ve kimlik politikaları ile sabitlenip kapılan klasik toplumsal hareketlerin de gücün kaybetmesine yol açmıştır. Bu yeni dönem 
tekno-dijital enformasyon ağı ve küresel bir imparatorluk gibi işleyen kapitalizmle birlikte yeniden formüle edilmelidir.

Deleuze'ün önerisi ise farklı tekilliklerin bir köksap oluşturacak biçimde birbirine eklemlenmesidir. Çoğunluk ve azınlık kavramları yerine sadece oluşların konulduğu, önceki deneyimlerin yeni deneyimler içinde hayatiyet bulduğu bu yeni durum yersizyurdsuz bir harekettir. Bir yere sabitlenmeyen ve kapılamayan çoğulluklardır. Bu yönleriyle Deleuze felsefesi arkadaşı olan Foucault felsefesi ile paralellikler taşır. Foucault'nun iktidarın soykütügünü çıkarıp, onun işlemesini sağlayan tekniklerini teşhir ettiği yerde Deleuze, iktidarın işlemesine olanak veren sabitliklerden kurtulmaya çalışır. Deleuze felsefesi bu yönüyle Fransız yapısalcılık sonrası felsefesinin en özgün felsefi düşüncelerinden bir olmaya devam etmektedir. 


\section{EXTENDED ABSTRACT}

\section{Basic Concepts And New Social Movements In Gilles Deleuze Philosophy}

Ümmet Erkan

Bartın University

Gilles Deleuze has a unique position in the French poststructuralist philosophy. Deleuze, who sees philosophy as the creation of new concepts, has developed a symbiotic relationship with F. Guittari. The books "Capitalism and Schizophrenia I-II", which they co-wrote, are extraordinary examples of this original thought. Deleuze refrained from making a classic history of philosophy while making philosophy. He developed a materialist and immanent philosophy by subjecting philosophers representing different traditions of thought such as Hume, Spinoza, Nietzsche, Bergson to an eclectic reading. His philosophy is far from a system philosophy.

Deleuze tried to make the philosophy of the new socio-political formation after 1968. During this period, capitalism gained a new and global form and new forms of domination began to develop. Classical relations of representation have lost their validity, class movements have become meaningless and human autonomy and freedom have been under heavy pressure. Homogenizing nation-state rhetoric has been replaced by more refined methods. In this new era, the whole has started to take its place and different pluralities have started to emerge. The main characteristic of this period, also referred to as the postmodern period, is singularities and difference.

The philosophy of Deleuze places a creative presence against the dialectical, humanist and metaphysical philosophies, the affirmation of life and the desire for power. Without relying on a higher purpose of life, it turns to actions that improve human beings. The interconnected plurality and the dynamic energy of life combine with the possibilities of the body. It is not based on a Cartesian or dialectical conflict, but on activism that creates rhizomes with new connections, cannot be fixed and is not confined and encoded to a particular space. His philosophy enabled him to enrich the concepts he produced with these new meanings.

Deleuze is opposed to subject philosophies, Hegel dialectics, structuralism and metaphysical philosophies that dominated philosophy in the early 20th 
century. Deleuze's philosophy is based on Hume, Spinoza, Nietzche and Bergson readings. Nietzsche argues that meaning cannot be considered separate from power relations and occupies an important place in his philosophical thought. Nietzsche affirmed life and highlighted the possibilities of man. In addition, Nietzche's notion of multitude influenced his notion of "creative multitude.. Creative multiplicity refers to a situation that is articulated to form a rhizome but does not lose its singularity. Thus, as an alternative to Hegelian dialectics, each identity is intended to engage in dialogue with the other without losing its identity and autonomy, instead of settling into its own independent consciousness by dealing with the other. In Bergson, Deleuze sets out from the concept of being dynamic and places human experiences at the center. Each experience gains meaning in interaction with another experience. He stated that Deleuze Spinoza is opposed to priorities and that consciousness is a passive structure that makes affect within the framework of emotions and impulses. Encounters play an important role in Spinoza philosophy. These encounters develop consciousness and bring it to a new and higher self. According to Deleuze, in his thinking, the concepts of good and evil are replaced by things that develop or hinder man.

One of the unique aspects of Deleuze is that it produces new concepts and makes its mark on the concepts. Among these concepts; war machine, grabber device, nomadology, deterritorialization, desire machine, body without organ, schizoanalysis, rhizome. Nomadic and deterritorialization are the most remarkable of these concepts. Deprivation is a mobility that makes the space unblemished and not fixed to a place like nomads. The state wants rough surfaces. Escape closes the roads. Stabilizes the speed. However, the nomadic place makes the place unwarranted. In this way, he manages to escape the control of the state. Capitalism works through the human body, affirms life and captures human energy. According to Deleuze, the way out against the coded body image is the "body without organ". The disorganized body dismantles all fixed identities engraved on it, expressing a chaotic, anarchic being. It excludes both male and female identities. Thus, it eliminates all distinctions such as gender and ethnicity based on bilateral oppositions. Rhizome, on the other hand, is a new form of relationship that allows different plurities to form. Rhizome is a multiplicity that can be fixed to a subject or object, but has no unity. Rhizomes that do not have a fixed order can easily connect with other subjects. Gives a handle from where it was broken. Thanks to these connections, pluralization and creativity will be possible. With the concept of 
schizoanalysis, Deleuze tried to criticize both classical and Lacanian psychoanalysis and capitalism. Capitalism encodes individuals and makes them part of the production process. Schizo (schizophrenic) is a person who cannot be coded and can avoid being coded. The grabbing device, the state, is based on profit, productivity, marketing and the advertising industry. The revolutionism of schizophrenia is a disruptive effect on capitalist codes.

Deleuze's philosophical ideas have also been a way out for anti-system movements towards new and global forms of domination of capitalism. Hardt and Negri expressed the new global situation as an "empire" and proposed multiplicity as a way out of the new situation. The state of multiplicity is a new and global form of resistance that can function against the global imperial order without destroying each other. These new global movements are structures that communicate through social media, are organized without a power, and focus on different political, ethnic, cultural and economic demands. It is a situation that can arise without eliminating one's own singularity but also creating a majority or minority situation. A resistance that cannot be coded by the system, constantly relocating and deforesting will accelerate the death of the system.

\section{Kaynakça / References}

Akay A.. (1991). Tekil düşünce. İstanbul: Afa Yayınları.

Akay, A. (1996a). Felsefe nedir? üzerine. Toplumbilim, V(Gilles Deleuze Özel Sayıs1), 15-18.

Akay, A. (1996b). Yersizyurdsuzlaşma Üzerine, Toplumbilim, V(Gilles Deleuze Özel Sayısı), 19-21.

Bell, D. (1999). The coming of post-industrial society. New York: Basic Books.

Bergson, H. (2017). Yaratıcı tekamül. (M. Ş. Tunç Çev.). İstanbul: Dergah Yayınları.

Castells, M. (2008). Ağg toplumunun Yükselişi. (E. Kılıç Çev.). İstanbul: Bilgi Üniversitesi Yayınları.

Deleuze, G. ve Parnet C. (1990). Diyaloglar. (A. Akay Çev.). İstanbul: Bağlam Yayınları.

Deleuze, G. ve Guittari, F. (1990). Kapitalizm ve şizofreni i - anti oedipus. (A. Akay Çev.). İstanbul: Bağlam Yayınları.

Deleuze, G. ve Guittari, F. (1993). Kapitalizm ve şizofreni ii - bin yayla. (A. Akay Çev.). İstanbul: Bağlam Yayınları. 
Deleuze, G. ve Guittari, F. (2000). Kafka, minör bir edebiyat için. (Ö. Uçkan, I. Ergüden Çev.). YKY: İstanbul.

Deleuze, G. ve Guittari, F. (2001). Felsefe nedir?. (6. Bsm). (T. Ilgaz Çev.). YKY: İstanbul.

Deleuze, G. (2006). Felsefe ve azınlık. (A. Soysal Çev.). Toplumbilim, V(Gilles Deleuze Özel Sayısı), 68-69.

Deleuze, G. (2000). Nietzsche ve felsefe, (F. Taylan Çev.). İstanbul: Norgunk Yayınları.

Deleuze, G. (2004). Proust ve göstergeler. (A. Meral Çev.). İstanbul: Kabalcı Yayınevi.

Deleuze G. (2005). Perikles ve verdi. (A. Akay Çev.). İstanbul: Bağlam Yayınları.

Deleuze, G. (2006). Bergsonculuk. (H. Yücefer Çev.). İstanbul: Otonom Yayıncilik.

Deleuze, G. (2008). Ampirizm ve öznellik. (E. Erbay Çev.). İstanbul: Norgunk Yayınları.

Deleuze, G. (2011). Spinoza, Pratik Felsefe. (A. Nahum ve U. Baker Çev.). İstanbul: Norgunk Yayınları.

Hardt, M. ve Negri, A. (2004). Çokluk imparatorluk çağında savaş ve demokrasi. (B. Yıldırım Çev.). İstanbul: Ayrıntı Yayınları.

Hardt, M. ve Negri, A. (2008). Imparatorluk. (A. Y1lmaz Çev.), (6. Bsm), İstanbul: Ayrintı Yayınları.

Holland, E. W. (2013). Şizoanalize giriş. (A. Utku ve M. Erkan Çev.). İstanbul: Otonom Felsefe Yayınlar.

Nas, F. (2018). Göç ve göçün yol açtığ1 sorunlar. (R. Şimşek Ed.), Göç Sosyolojisi, Ankara: Akademisyen Yayınları.

Soysal, A. (1996) Gücül ve güç metafizikçi olarak Gilles Deleuze, Toplumbilim, $V($ Gilles Deleuze Özel Sayısı), 23-25.

Spinoza, B. (2011). Etika. (H. Z. Ülken Çev.). Ankara: Dost Kitabevi.

Toffler, A. (2008). Üçüncü dalga. (S. Yeniçeri Çev.). İstanbul: Koridor Yayınları.

\section{Kaynakça Bilgisi / Citation Information}

Erkan, Ü. (2019). Gilles Deleuze felsefesinde temel kavramlar ve yeni toplumsal hareketler. OPUS-Uluslararası Toplum Araştırmaları Dergisi, 13(19), 2627-2652. DOI: 10.26466/opus.589030 